\title{
PENGARUH PENERAPAN GAME JEOPARDY DALAM PEMBELAJARAN REMEDIAL TERHADAP AKTIVITAS DAN HASIL BELAJAR MATA PELAJARAN IPS DI SD
}

\author{
Muh. Kadri Karim ${ }^{1}$, Mustaji ${ }^{2}$, Suhanadji ${ }^{3}$ \\ ${ }^{1}$ Mahasiswa Program Pascasarjana, Prodi Pendidikan Dasar, Universitas Negeri Surabaya, \\ ${ }^{2 \& 3}$ Dosen Pascasarjana, Prodi Pendidikan Dasar, Universitas Negeri Surabaya \\ e-mail: muhkadrikarim@yahoo.co.id
}

\section{Received : Novermber 2018}

Reviewed : Desember 2018

Accepted : Januari 2019

Published : Januari 2019
ABSTRACT

This study aimed at figuring out the influence of implementing Jeopardy game in learning remedial towards students' activities and learning outcomes in Social Science Subject for $5^{\text {th }}$ grade of Elementary School. The subject of this research was the students of $5^{\text {th }}$ grade in Elementary School Mamajang II, second semester and academic year of 2015-2016, who took remedy. This study belonged to experimental research. The research design used was quasi-experimental design which one of its type, nonequivalent control group design, was applied. In case of giving treatment, the experimental class implemented Jeopardy game; on contrary, the lecturing method was used in control class. The data of students' learning activities was obtained through observation before treatment section in both experimental and control class. Meanwhile, the learning outcomes were gained through pre-test and post-test in those two classes. The result of research showed that the students' activities score before treatment was 57,11 in average for experimental class and 59,38 for control class. Moreover, the averages of students' activities score when treatment section were 83,33 for experimental class and 71,46 for control class. Therefore, there were the differences score of students' activities between experimental and control class as 11,87. It can be concluded that there was significantincreaseof student activities as 26,22 to the experimental class. On the other hand, the increases of students' activities were only 12,08 in control class. In terms of students' learning outcomes, it was obtained pre-test score in control class; 45,00 in average and the average post-test score was 70,63. Contrastively, the learning outcomes for experimental class in pre-test were 46,25 in average and the post-test score in average was 86,56. According to the data, there was significant increase of learning outcomes as 40,31 to the experimental class and 25,63 to the control class. The research result was analyzed by using Independent Samples $T$ Test with SPSS for Windows version 21 as program assistance that showed the significant increase of implementing game Jeopardy towards students' learning activities and outcomes to the experimental class. According to the research result, it can be concluded that the hypothesis is proved if the implementation of Jeopardy game in remedial learning affects the students' activities and learning outcomes in Social Science Subject for $5^{\text {th }}$ grade of Elementary School.

Keywords: Remedial learning, Jeopardy game, activities, learning outcomes.

\section{ABSTRAK}

Penelitian ini bertujuan untuk mengetahui pengaruh penerapan game Jeopardy dalam pembelajaran remedial terhadap aktivitas dan hasil belajar mata pelajaran Ilmu Pengetahuan Sosial siswa kelas V SD. Subjek penelitian adalah siswa kelas V di SD Negeri Mamajang II semester II tahun pelajaran 2015-2016 yang mengikuti pembelajaran remedial. Penelitian ini merupakan penelitian eksperimen. Desain penelitian yang digunakan adalah Quasi Experimental Designs dengan menggunakan Nonequivalent Control Group Design. Pada saat perlakuan, kelas eksperimen menerapkan game Jeopardy, sedangkan kelas kontrol menggunakan pembelajaran konvensional (ceramah). Data aktivitas diperoleh melalui 
pengamatan sebelum perlakuan dan saat perlakuan pada kelas eksperimen dan kelas kontrol. Sedangkan, hasil belajar diperoleh melalui pretest dan posttest pada kelas eksperimen dan kelas kontrol. Hasil penelitian menunjukkan bahwa rata-rata aktivitas siswa sebelum perlakuan pada kelas eksperimen sebesar 57,11 dan kelas kontrol sebesar 59,38. Sedangkan, rata-rata aktivitas siswa saat perlakuan pada kelas eksperimen sebesar 83,33 dan kelas kontrol sebesar 71,46. Sehingga, selisih antara kelas eksperimen dengan kelas kontrol sebesar 11,87. Dapat disimpulkan bahwa terjadi peningkatan aktivitas belajar yang signifikan 26,22 pada kelas eksperimen. Sedangkan, pada kelas kontrol hanya sebesar 12,08. Untuk hasil belajar siswa diperoleh nilai pretest pada kelompok kontrol, yakni rata-rata nilai sebesar 45,00 dan pada posttest rata-rata nilai sebesar 70,63. Sedangkan hasil belajar kelas eksperimen pada saat pretest dengan rata-rata nilai sebesar 46,25 dan pada posttest rata-rata nilai sebesar 86,56. Berdasarkan data tersebut, terjadi peningkatan hasil belajar yang signifikan 40,31 pada kelas eksperimen. Sedangkan, pada kelas kontrol hanya sebesar 25,63. Hasil penelitian dianalisis dengan menggunakan uji Independent Samples T Test berbantuan program SPSS for Windows versi 21 yang menunjukkan bahwa ada pengaruh yang signifikan penerapan game Jeopardy terhadap aktivitas dan hasil belajar siswa pada kelas eksperimen.Berdasarkan hasil penelitian tersebut, maka dapat disimpulkan bahwa hipotesis terbukti bahwa penerapan game Jeopardy dalam pembelajaran remedial berpengaruh terhadap aktivitas dan hasil belajar IPS siswa kelas V SD.

Kata Kunci: Pembelajaran remedial, game Jeopardy, aktivitas, hasil belajar.

\section{PENDAHULUAN}

Berdasarkan karakteristik tujuan pembelajaran Ilmu Pengetahuan Sosial (IPS) tersirat sangat jelas bahwa IPS memiliki karakteristik materi pelajaran yang bersifat kompleks dan abstrak. Tidak dapat dipungkiri bahwa untuk mencapai tujuan mata pelajaran IPS tersebut pasti dijumpai adanya peserta didik yang mengalami kesulitan dalam aktivitas dan hasil belajar yang ingin dicapai dalam pembelajaran. Walaupun guru dalam pembelajaran reguler telah berupaya menerapkan metode, model dan menggunakan media dalam melaksanakan pembelajaran IPS.

Hal tersebut ditunjukkan dengan adanya data yang diperoleh peneliti terhadap ketuntasan hasil belajar siswa kelas V SD Negeri Mamajang II Kota Makassar kompetensi dasar mendeskripsikan perjuangan para tokoh pejuang pada masa penjajahan Belanda dan Jepang menunjukkan $57 \%$ yang tuntas dan $43 \%$ yang tidak tuntas dalam pembelajaran reguler. Kelemahan siswa tersebut terdapat pada beberapa indikator yang telah diajarkan. Untuk mengatasi masalah tersebut, setiap satuan pendidikan perlu menyelenggarakan program pembelajaran remedial atau perbaikan. Menurut Kustawan (2013: 50), pembelajaran remedial adalah suatu bentuk pengajaran yang bersifat membetulkan atau memperbaiki agar pengajaran menjadi lebih baik dari sebelumnya. Program remedial diberikan hanya untuk kompetensi dasar tertentu yang belum dikuasai oleh siswa. Menurut Abdurrahman (2012), pada tiap akhir kegiatan pembelajaran dari suatu unit pelajaran, guru melakukan evaluasi formatif dan setelah adanya evaluasi formatif anak-anak yang belum menguasai bahan pelajaran diberikan pembelajaran remedial.

Pembelajaran remidial dilakukan untuk mencapai kriteria ketuntasan minimal yang telah ditetapkan oleh guru. Salah satu permainan yang dapat diterapkan adalah game Jeopardy. Jeopardy adalah program kuis yang dirancang untuk menguji kemampuan peserta didik dalam mengidentifikasi dan mengingat informasi faktual. Yang berbeda dari game Jeopardy dan alasan untuk memilihnya adalah, bahwa pertanyaan dan jawabannya yang dibalik.

Pembelajaran remedial dengan menerapkan game Jeopardy dapat membantu siswa belajar secara mandiri. Hal ini akan meningkatkan kualitas pembelajaran remedial sehingga siswa yang mengalami masalah dalam aktivitas dan hasil belajar dituntaskan dalam pembelajaran remedial.

Alasan lain mengapa game Jeopardy dipilih sebagai metode dalam pembelajaran remedial adalah, setiap kategori mengukur bidang pengetahuan yang berbeda sesuai dengan Taksonomi Bloom. Pertanyaan dengan nilai seratus mengukur kemampuan identifikasi dan mengingat informasi. Pertanyaan dengan nilai dua ratus mengukur kemampuan peserta dalam memahami atau mengaplikasikan informasi. Pertanyaan bernilai tiga ratus fokus pada aplikasi, analisa dan sintesa informasi.

Berdasarkan pemaparan di atas, peneliti meyakini bahwa proses pembelajaran remedial dengan penerapan game Jeopardy dapat memengaruhi aktivitas dan hasil 
belajar siswa kelas V SD pada mata pelajaran ilmu pengetahuan sosial dengan standar kompetensi menghargai peranan tokoh pejuang dan masyarakat dalam mempersiapkan dan mempertahankaan kemerdekaan Indonesia, kompetensi dasar mendeskripsikan perjuangan para tokoh pejuang pada masa penjajahan Belanda dan Jepang.

\section{METODE PENELITIAN}

Pendekatan yang digunakan dalam penelitian ini adalah pendekatan kuantitatif. Berdasarkan rumusan masalah, maka penelitian ini dikategorikan ke dalam penelitian eksperimen dan model penelitian eksperimen yang digunakan dalam penelitian ini adalah eksperimen quasi Nonequivalent Control Group design. Penelitian eksperimen digunakan dalam penelitian ini karena peneliti ingin memanipulasi variabel bebas atau memberikan perlakuan (treatment) serta ingin mengetahui pengaruh perlakuan (treatment) tersebut.

Perlakuan (treatment) yang dimaksud dalam penelitian ini adalah penerapan game Jeopardy dalam pembelajaran remedial pada kelompok eksperimen.

Penelitian ini bertujuan untuk mengetahui seberapa signifikan pengaruh penerapan game Jeopardy dalam pembelajaran remedial terhadap aktivitas dan hasil belajar IPS siswa kelas V. Subjek penelitian adalah siswa kelas V A dan V B SD Negeri Mamajang II yang mengikuti pembelajaran remedial. Penelitian ini merupakan penelitian eksperimen semu (quasy eksperiment) dengan rancangan penelitian yang digunakan adalah Non Equivalent Control Group Design. Kelas eksperimen menerapkan game Jeopardy dalam pembelajaran, sedangkan kelas kontrol menggunakan pembelajaran konvensional. Data penelitian diperoleh lembar pengamatan aktivitas serta pretest dan posttest pada kelas eksperimen maupun kelas kontrol.

Penelitian ini difokuskan pada indikator yang tidak tercapai dalam pembelajaran reguler materi tokoh-tokoh pejuang zaman penjajahan belanda dan jepang di kelas $\mathrm{V}$ Sekolah Dasar. Setiap perangkat yang digunakan dalam penelitian diujicoba di SD Negeri Tanggul Patompo I. Kelas ujicoba digunakan untuk mengetahui validitas dan realibilitas alat penilaian aktivitas dan hasil belajar siswa sebelum digunakan pada penelitian. Setelah di hitung validitas dan realibilitasnya menunjukkan hasil yang valid dan reliabel sesuai kriteria yang ditetapkan sehingga alat penilaian dianggap layak untuk digunakan dalam penelitian..

Setelah intrumen penilaian valid dan reabel langkah selanjutnya memulai penelitian dengan pengumpulan data aktivitas belajar siswa dengan intstrumen lembar aktivitas belajar. Sedangkan tes hasil belajar awal siswa berupa tes hasil belajar awal siswa pada kelas eksperimen dan pada kelas kontrol.

Setelah data diproleh kemudian data diolah dengan menghitung normalitas dan homogenitasnya serta diuji hasilnya untuk mengecek apakah kelas eksperimen dan kelas kontrol yang digunakan layak atau tidak dijadikan sebagai subjek penelitian. Hal ini dimaksudkan agar penelitian menghasilkan data yang akurat tentang penerapan game Jeopardy dalam pembelajaran remedial yang akan digunakan pada penelitian.

Selanjutnya setelah kelas ekspertimen dan kelas kontrol dinyatakan layak dijadikan sebagai subjek penelitian, diadakan kegiatan pembelajaran dengan memberi perlakuan pada masing-masing kelas. Kelas eksperimen dengan penerapan game Jeopardy dalam pembelajaran remedial, sedangkan pada kelas kontrol dengan menggunakan pembelajaran konvensional (ceramah dan tanya jawab).

Kegiatan pengumpulan data aktivitas siswa saat perlakuan dan posttest hasil belajar siswa setelah perlakuan bertujuan untuk mengetahui pengaruh penerapan game Jeopardy dalam pembelajaran remedial terhadap aktivitas dan hasil belajar siswa.

\section{HASIL PENELITIAN DAN PEMBAHASAN}

\section{A. Deskripsi Data Hasil Penelitian}

Sesuai dengan rumusan masalah dan hipotesis dalam penelitian ini, maka data yang diolah dalam penelitian ini berasal dari data hasil pengukuran aktivitas belajar siswa dan hasil belajar siswa baik pada pretest maupun posttest. Adapun data hasil penelitian peneliti jabarkan sebagai berikut.

1. Data Hasil Penilaian Aktivitas Belajar Siswa.

Data hasil pengukuran tingkat aktivitas belajar siswa sebelum perlakuan dan saat perlakuan diperoleh dengan cara mengamati aktivitas belajar siswa pada pembelajaran IPS baik pada kelas V A sebagai kelas eksperimen dan Kelas V B sebagai kelas kontrol. Proses observasi dilakukan oleh guru SD Negeri Mamajang II Makassar yaitu Ibu Sunggu, S.Pd. selaku observer I dan Ibu Armiyati, S.Pd. selaku observer II.

Pengukuran awal aktivitas belajar siswa pada kelas eksperimen dan kontrol dilakukan pada hari Sabtu, 5 Maret 2016. Siswa yang diamati berjumlah 16 orang dan pada kelas eksperimen dan 16 orang pada kelas kontrol.

Sedangkan untuk data hasil pengukuran saat perlakuan aktivitas belajar siswa diperoleh dengan mengamati aktivitas belajar siswa pada saat proses 
pembelajaran IPS dengan penerapan permainan berupa game Jeopardy pada kelas V A (kelas eksperimen) dan proses pembelajaran IPS dengan menggunakan metode konvensional pada kelas V B (kelas kontrol). Pembelajaran dilaksanakan pada tanggal 8 maret 2016 secara paralel pada kelas eksperimen dan kelas kontrol.

proses pembelajaran materi tokoh-tokoh pejuang pada zaman penjajahan belanda dan jepang dilaksanakan dalam satu kali pertemuan baik pada kelas eksperimen maupun kontrol.

Ringkasan data hasil pengukuran aktivitas belajar siswa pada kelas eksperimen dan kelas kontrol dapat dilihat pada tabel 1. berikut.

Tabel 1.

Rata-Rata Nilai Aktivitas Belajar Siswa

\begin{tabular}{|c|c|c|c|c|c|}
\hline \multirow{3}{*}{ No } & \multirow{3}{*}{ Nilai } & \multicolumn{4}{|c|}{ Aktivitas Belajar Siswa } \\
\hline & & \multicolumn{2}{|c|}{ Kelas Kontrol } & \multicolumn{2}{|c|}{ Kelas Eksperimen } \\
\hline & & $\begin{array}{c}\text { Sebelum } \\
\text { Perlakuan }\end{array}$ & $\begin{array}{c}\text { Saat } \\
\text { Perlakuan }\end{array}$ & $\begin{array}{c}\text { Sebelum } \\
\text { Perlakuan }\end{array}$ & $\begin{array}{c}\text { Saat } \\
\text { Perlakuan }\end{array}$ \\
\hline 1 & $\begin{array}{l}\text { Rata- } \\
\text { Rata }\end{array}$ & 59,38 & 71,46 & 57,11 & 83,33 \\
\hline 2 & $\begin{array}{c}\text { Nilai } \\
\text { Tertinggi }\end{array}$ & 73,33 & 90,00 & 63,33 & 90,00 \\
\hline 3 & $\begin{array}{c}\text { Nilai } \\
\text { Terendah }\end{array}$ & 50,00 & 60,00 & 46,67 & 60,00 \\
\hline
\end{tabular}

(Sumber : Data yang diolah)

Dari Tabel 1 diketahui bahwa data aktivitas belajar siswa sebelum perlakuan pada kelompok kontrol, dengan jumlah siswa 16 orang, nilai terendah 50,00 dan nilai tertinggi 73,33 dengan rata-rata nilai aktivitas belajar sebesar 59,38. Pada saat perlakuan nilai terendah 60,00 dan nilai tertinggi 90,00 dan dengan rata-rata nilai aktivitas belajar sebesar 71,46. Sedangkan hasil belajar kelas eksperimen dengan jumlah siswa 16 anak, pada saat sebelum perlakuan nilai terendah 46,67 dan nilai tertinggi sebesar 63,33 dengan rata-rata nilai aktivitas belajar sebesar 57,11. Sedangkan pada saat perlakuan nilai terendah 60,00 dan nilai tertinggi 90,00 dengan rata-rata nilai aktivitas belajar sebesar 83,33.

Dari Tabel 1 diketahui bahwa perolehan nilai aktivitas siswa sebelum perlakuan pada kelas eksperimen sebesar 57,11 dan perolehan nilai kelas kontrol sebesar 59,38. Sehingga, selisih antara kelas eksperimen dengan kelas kontrol sebesar 2,27. Hal ini menunjukkan rata-rata aktivitas siswa sebelum perlakuan pada kedua kelas tersebut tidak ada perbedaan yang signifikan.

Sedangkan rata-rata nilai saat perlakuan siswa pada kelas eksperimen sebesar 83,33 dan perolehan nilai kelas kontrol saat perlakuan sebesar 71,46. Sehingga, selisih antara kelas eksperimen dengan kelas kontrol sebesar
11,87. Hal ini menunjukkan rata-rata aktivitas siswa saat perlakuan pada kedua kelas tersebut ada perbedaan yang signifikan. Untuk lebih jelasnya, data hasil pengukuran aktivitas belajar siswa dapat dilihat pada gambar 1 berikut.

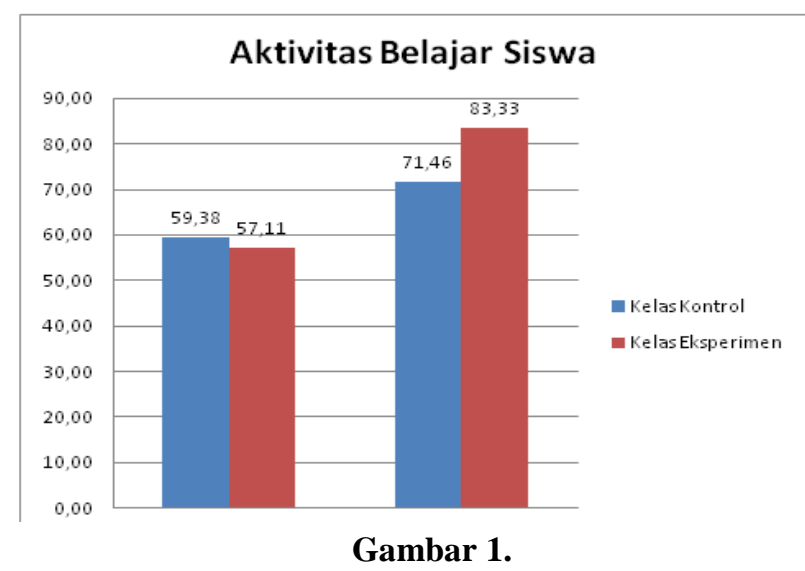

Persentase Nilai Rata-Rata Aktivitas Belajar Siswa

Berdasarkan gambar 1. di atas, dapat disimpulkan bahwa terjadi peningkatan aktivitas belajar yang signifikan 26,22 pada kelas eksperimen. Sedangkan, pada kelas kontrol hanya sebesar 12,08.

\section{Data Hasil Belajar Siswa}

Data hasil belajar IPS pretest dan posttest pada materi tokoh-tokoh pejuang zaman penjajahan belanda dan jepang baik pada kelompok kontrol dan kelompok eksperimen disajikan pada tabel 2. berikut.

Tabel 2.

Rata-Rata Hasil Belajar Siswa

\begin{tabular}{|c|c|c|c|c|c|}
\hline \multirow{3}{*}{ NO } & \multirow{3}{*}{ NILAI } & \multicolumn{4}{|c|}{ Hasil Belajar Siswa } \\
\hline & & \multicolumn{2}{|c|}{ Kelas Kontrol } & \multicolumn{2}{|c|}{ Kelas Eksperimen } \\
\hline & & Pretest & Posttest & Pretest & Posttest \\
\hline 1 & Rata-Rata & 45,00 & 70,63 & 46,25 & 86,56 \\
\hline 2 & Nilai Tertinggi & 70 & 95 & 65 & 100 \\
\hline 3 & Nilai Terendah & 35 & 45 & 30 & 75 \\
\hline
\end{tabular}

(Sumber : Data yang diolah)

Dari Tabel 2. diketahui bahwa pada pretest data hasil belajar siswa pada kelompok kontrol, dengan jumlah siswa 16 orang, mencapai nilai terendah 35 dan nilai tertinggi 70 dengan rata-rata nilai hasil belajar siswa sebesar 45,00 . Pada posttest nilai terendah 45 dan nilai tertinggi 95 dan dengan rata-rata nilai hasil belajar siswa sebesar 70,63. Sedangkan hasil belajar kelompok eksperimen dengan jumlah siswa 16 anak, pada saat pretest nilai terendah 30 dan skor tertinggi sebesar 65 dengan ratarata nilai hasil belajar siswa sebesar 46,25 . Pada posttest 
nilai terendah 75 dan nilai tertinggi 100 dan dengan ratarata nilai hasil belajar siswa sebesar 86,56.

Dari Tabel 4.6 dapat diketahui bahwa perolehan nilai pretest hasil belajar siswa pada kelas eksperimen dan perolehan nilai pretest kelas kontrol tersebut tidak ada perbedaan yang signifikan. Sedangkan rata-rata nilai posttest siswa pada kelas eksperimen dan perolehan nilai posttest kelas kontrol menunjukkan rata-rata posttest hasil belajar siswa pada kedua kelas tersebut ada perbedaan yang signifikan. Untuk lebih jelasnya perbandingan nilai ratarata persentase hasil belajar siswa dapat dilihat pada gambar 2 berikut.

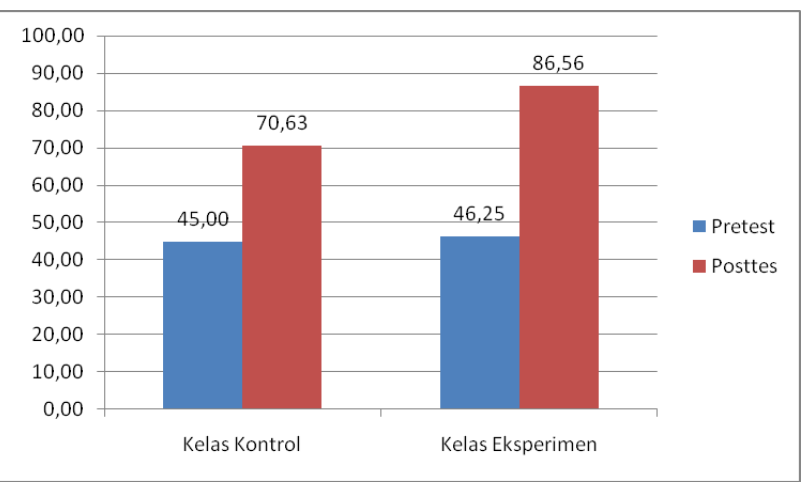

Gambar 2.

Persentase Nilai Rata-Rata Hasil Belajar Siswa

Berdasarkan gambar 2. di atas, dapat disimpulkan bahwa terjadi peningkatan hasil belajar yang signifikan 40,31 pada kelas eksperimen. Sedangkan, pada kelas kontrol hanya sebesar 25,63.

\section{B. Uji Hipotesis}

1. Hasil Uji Prasyarat Hipotesis Data

Setelah data hasil penelitian didapatkan, maka data akan diolah untuk pengujian hipotesis. Sebelum melakukan uji hipotesis, terlebih dahulu dilakukan pengujian prasyarat analisis data, yaitu uji normalitas dan homogenitas. Uji prasyarat ini bertujuan untuk mengetahui apakah data yang diperoleh berdistribusi normal dan mempunyai varians yang sama (homogen) atau berbeda, sehingga bisa ditarik kesimpulan jenis hipotesis akhir yang akan digunakan (parametrik atau non-parametrik). Uji prasyarat ini dilakukan dengan menggunakan bantuan komputer program Statistical Package for the Sosial Sciences(SPSS) 21 for Windows. Adapun hasil yang didapat pada uji prasyarat analisis data sebagai berikut.

\section{a. Uji Normalitas Data}

Uji normalitas dilakukan pada data aktivitas sebelum dan saat perlakuan serta pretest dan posttest hasil belajar siswa dengan tujuan untuk mengetahui data berdistribusi normal atau tidak. Uji normalitas data tersebut dihitung dengan menggunakan uji Lilefors Shapiro Wilk. Adapun hasil uji normalitas data aktivitas dan hasil belajar pada penelitian ini adalah sebagai berikut.

1) Hasil Uji Normalitas Data Aktivitas Belajar Siswa

Data hasil uji normalitas aktivitas belajar siswa dapat dilihat pada tabel 3. berikut.

Tabel 3.

Hasil Uji Normalitas Aktivitas Belajar Siswa

\begin{tabular}{|c|c|c|c|}
\hline Taraf Sig. & Uji Normalitas & $\begin{array}{l}\text { Sebelum } \\
\text { perlakuan }\end{array}$ & $\begin{array}{c}\text { Saat } \\
\text { perlakuan }\end{array}$ \\
\hline 0,05 & $\begin{array}{l}\text { Uji Lilefors } \\
\text { shapiro Wilk }\end{array}$ & 0,96 & 0,075 \\
\hline Kesimpulan & $\begin{array}{l}\text { Asymp.Sig. }(2- \\
\text { tailed) }>0,05\end{array}$ & normal & normal \\
\hline
\end{tabular}

(Sumber : SPSS 21 for windows)

Dari tabel 3. berdasarkan hasil pengujian diketahui bahwa nilai signifikansi (Sig.) aktivitas belajar siswa sebelum perlakuan yaitu 0,96 Dengan demikian data berdistribusi normal. Pada saat perlakuan hasil pengujian diketahui bahwa nilai signifikansi (Sig.) aktivitas belajar siswa yaitu 0,075. Data posttest tersebut menunjuk hasil lebih besar dari 0,05 yang berarti data berdistribusi normal.

2) Hasil Uji Normalitas Data Hasil Belajar Siswa

Adapun hasil uji normalitasdata hasil belajar siswa dapat dilihat pada tabel 4 . berikut.

Tabel 4.

Hasil Uji Normalitas Tes Hasil Belajar Siswa

\begin{tabular}{clcc}
\hline Taraf Sig. & Uji Normalitas & Pretest & Postest \\
0,05 & $\begin{array}{l}\text { Uji Lilefors } \\
\text { shapiro Wilk } \\
\text { Asymp.Sig. }(2- \\
\text { Kesimpulan }\end{array}$ & 0,72 & 0,255 \\
\hline tailed $)>0,05$ & normal normal \\
\hline
\end{tabular}

Dari tabel 4. berdasarkan hasil pengujian diketahui bahwa nilai Signifikansi(Sig.) hasil belajar siswa pada pretest yaitu 0,72 Dengan demikian data pretest berdistribusi normal. Pada posttest hasil pengujian diketahui bahwa nilai signifikansi(Sig.) hasil belajar siswa yaitu 0,255. Data posttest tersebut menunjuk hasil lebih besar dari 0,05 yang berarti data berdistribusi normal.

\section{b. Uji Homogenitas}

Uji homogenitas dilakukan pada data sebelum dan saat perlakuan serta pretest dan posttest dengan tujuan untuk mengetahui data bervarian sama (homogen) atau berbeda. Uji homogenitas data tersebut dihitung dengan 
menggunakan uji Lavene's Test. Adapun hasil uji homogenitas data aktivitas dan hasil belajar pada penelitian ini adalah sebagai berikut.

1) Hasil Uji Homogenitas Data Aktivitas Belajar Siswa

Hasil uji homogenitas data aktivitas belajar siswa dapat dilihat pada tabel 5 berikut.

Tabel 5.

Hasil Uji Homogenitas Aktivitas Belajar Siswa.

\begin{tabular}{ccccc}
\hline & Levene statistic & $d f 1$ & $d f 2$ & Sig. \\
Pretest & 0,002 & 1 & 30 & 0,963 \\
Postest & 1,837 & 1 & 30 & 0,185 \\
\hline \multicolumn{4}{c}{ (Sumber : SPSS 21 for windows) }
\end{tabular}

Berdasarkan Tabel 5. hasil pengujian diketahui bahwa nilai signifikansi (Sig.) data aktivitas belajar siswa sebelum perlakuan (kelas eksperimen dan kelas kontrol) yaitu $0,963>0,05$ yang berarti bahwa data sebelum perlakuan mempunyai varian yang sama (homogen). Pada saat perlakuan hasil pengujian diketahui bahwa nilai signifikansi (Sig.) aktivitas belajar siswa (kelas eksperimen dan kelas kontrol) yaitu 0,185 > 0,05 yang menunjukkan bahwa data saat perlakuan mempunyai varian yang sama atau homogen.

2) Hasil Uji Homogenitas Data Hasil Belajar Siswa

Adapun hasil uji homogenitas data hasil belajar siswa dapat dilihat pada tabel 6 . berikut.

Tabel 6.

Hasil Uji Homogenitas Aktivitas Belajar Siswa

\begin{tabular}{ccccc}
\hline & Levene statistic & $d f 1$ & $d f 2$ & Sig. \\
Pretest & 2,903 & 1 & 30 & 0,099 \\
Postest & 3,446 & 1 & 30 & 0,073 \\
\hline \multicolumn{4}{r}{ (Sumber : SPSS 21 for windows) }
\end{tabular}

Berdasarkan hasil pengujian diketahui bahwa nilai signifikansi (Sig.) data hasil belajar siswa pada pretest (kelas eksperimen dan kelas kontrol) yaitu 0,099>0,05 yang menunjukkan bahwa data pretest mempunyai varian yang sama (homogen). Pada postest hasil pengujian diketahui bahwa nilai signifikansi (Sig.) data hasil belajar siswa (kelas eksperimen dan kelas kontrol) yaitu 0,073 > 0,05 yang berarti bahwa data posttest mempunyai varian yang sama (homogen).

Berdasarkan hasil uji prasyarat hipotesis (normalitas dan homogenitas) data aktivitas sebelum dan saat perlakuan serta hasil belajar siswa pada pretest dan posttest kelas kontrol dan kelas eksperimen yang menunjukkan bahwa data berdistribusi normal dan homogen. Maka dapat ditarik kesimpulan bahwa untuk uji hipotesis akhir memenuhi syarat menggunakan jenis uji statistik parametrik yang dalam hal ini independent sample t test.
2. Hasil Uji Hipotesis

Uji hipotesis yang digunakan dalam penelitian ini adalah jenis uji statistik parametrik dengan menggunakan independent $t$ test. Uji ini digunakan untuk mengambil keputusan apakah hipotesis penelitian diterima atau ditolak. Dengan hipotesis sebagai berikut:

$\mathrm{Ho}=$ tidak ada perbedaan yang signifikan aktivitas dan hasil belajar siswa pada kelas eksperimen dan kelas kontrol.

$\mathrm{Ha}=$ ada perbedaan yang signifikan aktivitas dan hasil belajar siswa pada kelas eksperimen dan kelas kontrol. berikut:

Pengambilan keputusan dengan nilai $t_{\text {hitung }}$ sebagai

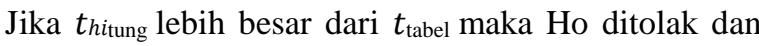
Ha diterima.

Jika $t_{h i t u n g}$ lebih kecil dari $\mathrm{t}_{\text {tabel }}$ maka Ho diterima dan Ha ditolak.

Pengambilan keputusan dengan nilai Sig. sebagai berikut:

a. Apabila nilai Sig.> 0,05 maka Ho diterima dan $\mathrm{Ha}$ ditolak.

b. Apabila nilai Sig. $<0,05$ maka Ho ditolak dan $\mathrm{Ha}$ diterima.

Pengujian analisis akhir dilakukan dengan bantuan komputer program SPSS 21 for windows independent sample t-test pada taraf signifikansi 5\%. Uji ini digunakan untuk mengetahui ada atau tidaknya pengaruh penerapan Game Jeopardy dalam pembelajaran remedial terhadap aktivitas dan hasil belajar IPS di kelas V SD antara kelas ekperimen dan kelas kontrol. Adapun cara membaca hasil pengujian pada baris equal variance assumed karena varian data homogen. Hasil uji hipotesis akhir data aktivitas dan hasil belajar siswa dijabarkan sebagai berikut.

a. Hasil Uji-t Data sebelum Perlakuan

Hasil uji-t data pretest aktivitas dan hasil belajar siswa adalah sebagai berikut.

1) Hasil Uji-t Data Aktivitas Belajar Siswa Sebelum Perlakuan

Hasil uji hipotesis data aktivitas belajar siswa pada sebelum Perlakuan terdapat pada tabel 7. berikut.

Tabel 7.

Hasil Uji Hipotesis Data Aktivitas Belajar Siswa pada sebelum Perlakuan.

\begin{tabular}{|c|c|c|c|c|c|}
\hline & $\mathrm{t}_{\text {hitung }}$ & $\mathrm{t}_{\text {tabel }}$ & $d f$ & $\begin{array}{c}\text { Sig. } \\
(2- \\
\text { tailed })\end{array}$ & $\alpha$ \\
\hline $\begin{array}{c}\text { Equal variances } \\
\text { assumed }\end{array}$ & 0,992 & \multirow{2}{*}{2,037} & 30 & 0,329 & \multirow{2}{*}{0,05} \\
\hline $\begin{array}{c}\text { Equal variances } \\
\text { notassumed }\end{array}$ & 0,992 & & 29,726 & 0,329 & \\
\hline
\end{tabular}


Berdasarkan hasil uji-t pada Tabel 7., dapat diketahui bahwa $t_{\text {hitung }}$ untuk data aktivitas belajar siswa sebelum perlakuan (kelas ekperimen dan kelas kontrol) sebesar 0,992 ( $d f$ 32) dan Sig.(2-tailed) sebesar 0,329. Untuk lebih jelasnya hasil uji-t data pretest hasil belajar siswa dapat dilihat pada lampiran. Dari hasil tersebut menunjukkan $\mathrm{t}_{\text {hitung }} 0,992(d f 32)<\mathrm{t}_{\text {tabel }} 2,037$ (df 32) dan nilai Sig. (2-tailed) 0,329>0,05 yang berarti Ho diterima dan Ha ditolak. Dengan demikian tidak ada perbedaan yang signifikan antara aktivitas siswa pada kelas eksperimen dengan aktivitas siswa pada kelas kontrol.

2) Hasil Uji-t Data Pretest Hasil Belajar Siswa

Hasil uji hipotesis data hasilbelajar siswa pada pretest terdapat pada tabel 8 . berikut.

Tabel 8.

Hasil Uji Hipotesis Data Hasil Belajar Siswa pada Pretest.

\begin{tabular}{cccccc}
\hline & $\mathrm{t}_{\text {hitung }}$ & $\mathrm{t}_{\text {tabel }}$ & $\mathrm{df}$ & $\begin{array}{c}\text { Sig. } \\
(2- \\
\text { tailed) }\end{array}$ & $\alpha$ \\
$\begin{array}{c}\text { Equal variances } \\
\text { assumed }\end{array}$ & 0,317 & 2,03 & 30 & 0,753 & \\
$\begin{array}{c}\text { Equal variances } \\
\text { notassumed }\end{array}$ & 0,317 & 7 & $\begin{array}{c}28,25 \\
8\end{array}$ & 0,753 & 0,05 \\
\hline & (Sumber : SPSS 21 for windows)
\end{tabular}

Berdasarkan hasil uji-t pada Tabel 8 dapat diketahui bahwa thitung untuk data pretest hasil belajar siswa (kelas ekperimen dan kelas kontrol) sebesar 0,317 ( $d f$ 32) dan Sig.(2-tailed) sebesar 0,753. Untuk lebih jelasnya hasil uji-t data pretest hasil belajar siswa dapat dilihat pada lampiran. Dari hasil tersebut menunjukkan $\mathrm{t}_{\text {hitung }} 0,317$ (df 32) $<\mathrm{t}_{\text {tabel }}$ 2,037 (df 32) dan nilai Sig. (2-tailed) 0,753 > 0,05 yang berarti Ho diterima dan Ha ditolak. Dengan demikian tidak ada perbedaan yang signifikan antara hasil belajar siswa pada kelas eksperimen dengan siswa pada kelas kontrol.

b. Hasil Uji-t Data Setelah perlakuan

1) Hasil Uji-t Data Aktivitas Belajar Siswa Saat Perlakuan

Hasil uji hipotesis data aktivitas belajar siswa pada saat perlakuan secara lengkap terdapat pada lampiran. Sedangkan secara ringkas dapat dilihat pada tabel 9 . berikut.

Tabel 9.

Hasil Uji Hipotesis Data Aktivitas Belajar Siswa pada Saat Perlakuan.

\begin{tabular}{lccccc}
\hline & $\mathrm{t}_{\text {hitung }}$ & $\mathrm{t}_{\text {tabel }}$ & $\mathrm{df}$ & $\begin{array}{c}\text { Sig. } \\
(2- \\
\text { tailed })\end{array}$ & $\alpha$ \\
& & & 30 & 0,000 & \\
$\begin{array}{l}\text { Equal variances } \\
\text { assumed }\end{array}$ & 4,364 & & & & 0,05 \\
$\begin{array}{l}\text { Equal variances } \\
\text { notassumed }\end{array}$ & 4,364 & 2,037 & 28,850 & 0,000 & \\
\hline
\end{tabular}

(Sumber : SPSS 21 for windows)
Berdasarkan hasil uji-t pada tabel 9. data aktivitas belajar siswa saat perlakuan (kelas ekperimen dan kelas kontrol) dapat diketahui bahwa $t_{\text {hitung }}$ sebesar 4,364 (df 32) dan nilai Sig.(2-tailed) sebesar 0,000. Hasil tersebut menunjukkan $\mathrm{t}_{\text {hitung }} 4,364$ (df 32) > $\mathrm{t}_{\text {tabel }} 2,037$ (df 32) dan nilai Sig.(2-tailed) 0,000 < 0,05 yang berarti Ho ditolak dan Ha diterima. (ada perbedaan yang signifikan aktivitas belajar siswa pada kelas eksperimen dan kelas kontrol). Maka dapat disimpulkan bahwa ada pengaruh yang signifikan dari penerapan game Jeopardy dalam pembelajaran remedial terhadap aktivitas belajar IPS di kelas V SD.

2) Hasil Uji-t Data Posttest Hasil Belajar Siswa

Hasil uji hipotesis data hasil belajar siswa pada posttest secara lengkap terdapat pada pada lampiran. sedangkan secara ringkas dapat dilihat pada tabel 10 . berikut.

Tabel 10.

Hasil Uji Hipotesis Data Hasil Belajar Siswa pada Posttest

\begin{tabular}{cccccc} 
& $\mathrm{t}_{\text {hitung }}$ & $\mathrm{t}_{\text {tabel }}$ & $d f$ & $\begin{array}{c}\text { Sig. } \\
(2- \\
\text { tailed })\end{array}$ & $\alpha$ \\
$\begin{array}{c}\text { Equal } \\
\text { variances } \\
\text { assumed } \\
\begin{array}{c}\text { Equal } \\
\text { variances }\end{array}\end{array}$ & 4,247 & & 30 & 0,000 & \\
notassumed & 4,247 & 2,03 & & & 0,05 \\
\hline
\end{tabular}

(Sumber : SPSS 21 for windows)

Berdasarkan hasil uji-t pada tabel 10. data posttest hasil belajar siswa (kelas ekperimen dan kelas kontrol) dapat diketahui bahwa $t_{\text {hitung }}$ sebesar 4,247 (df 32) dan nilai Sig.(2-tailed) sebesar 0,000. Hasil tersebut menunjukkan $\mathrm{t}_{\text {hitung }} 4,247(d f 32)>\mathrm{t}_{\text {tabel }}$ 2,037 (df 32) dan nilai Sig.(2tailed) $0,000<0,05$ yang berarti Ho ditolak dan Ha diterima (ada perbedaan yang signifikan hasil belajar siswa pada kelas eksperimen dan kelas kontrol). Maka dapat disimpulkan bahwa terbukti ada pengaruh yang signifikan dari penerapan Game Jeopardy dalam pembelajaran remedial terhadap hasil belajar IPS di kelas V SD pada materi tokoh-tokoh pejuang zaman penjajahan belanda dan jepang.

\section{SIMPULAN}

Berdasarkan hasil penelitian yang telah dilaksanakan, dapat ditarik kesimpulan sebagai berikut:

Penerapan game Jeopardy dalam pembelajaran remedial di kelas $\mathrm{V}$ sekolah dasar berpengaruh terhadap aktivitas belajar pada mata pelajaran ilmu pengetahuan sosial. Hasil penelitian menunjukkan bahwa perolehan nilai 
aktivitas siswa sebelum perlakuan pada kelas eksperimen sebesar 57,11 dan perolehan nilai sebelum perlakuan kelas kontrol sebesar 59,38. Sedangkan, rata-rata nilai saat perlakuan siswa pada kelas eksperimen sebesar 83,33 dan perolehan nilai saat perlakuan kelas kontrol sebesar 71,46. Hal ini menunjukkan rata-rata aktivitas siswa saat perlakuan pada kedua kelas tersebut ada perbedaan yang signifikan. Terjadi peningkatan aktivitas belajar yang signifikan 26,22 pada kelas eksperimen. Sedangkan, pada kelas kontrol hanya sebesar 12,08.

Berdasarkan hasil uji-t pada data aktivitas belajar siswa saat perlakuan (kelas ekperimen dan kelas kontrol) dapat diketahui bahwa thitung sebesar 4,364 (df 32) dan nilai Sig.(2-tailed) sebesar 0,000. Hasil tersebut menunjukkan thitung 4,364 (df 32) > ttabel 2,037 (df 32) dan nilai Sig.(2-tailed) 0,000 < 0,05 yang berarti Ho ditolak dan Ha diterima.

Penerapan game Jeopardy dalam pembelajaran remedial di kelas $\mathrm{V}$ sekolah dasar berpengaruh terhadap hasil belajar siswa pada mata pelajaran ilmu pengetahuan. Hasil penelitian menunjukkan bahwa Perolehan nilai pretest hasil belajar siswa pada kelompok kontrol, yakni rata-rata nilai sebesar 45,00 dan pada posttest rata-rata nilai hasil belajar siswa sebesar 70,63. Sedangkan hasil belajar kelompok eksperimen dengan jumlah siswa 16 anak, pada saat pretest dengan rata-rata nilai sebesar 46,25 dan pada posttest rata-rata nilai hasil belajar siswa sebesar 86,56. Berdasarkan data tersebut, terjadi peningkatan hasil belajar yang signifikan 40,31 pada kelas eksperimen. Sedangkan, pada kelas kontrol hanya sebesar 25,63.

Hasil uji-t pada data posttest hasil belajar siswa (kelas ekperimen dan kelas kontrol) dapat diketahui bahwa thitung sebesar 4,247 (df 32) dan nilai Sig.(2-tailed) sebesar 0,000. Hasil tersebut menunjukkan thitung 4,247 (df 32) > ttabel 2,037 (df 32) dan nilai Sig.(2-tailed) 0,000 $<0,05$ yang berarti Ho ditolak dan Ha diterima.

\section{SARAN}

1. Game Jeopardy dalam pembelajaran remedial di kelas V sekolah dasar pada mata pelajaran ilmu pengetahuan sosial dengan materi tokoh pejuang pada masa penjajahan Belanda dan Jepang dapat digunakan untuk meningkatkan aktivitas dan hasil belajar siswa. Penerapan game tersebut sebaiknya mengikuti model pembelajaran kooperatif tipe Team Game Tournament (TGT). Sebelum bermain game guru terlebih dahulu memilih tiga orang anak yang bertugas sebagai timer, scorer, dan navigator. Pada saat bermain setiap kelompok diberi pertanyaan wajib dan disediakan pertanyaan rebutan. Untuk mengaktifkan siswa pada saat bermain game, guru memberi kesempatan kepada siswa untuk mempelajari bahan ajar yang telah disediakn dan sumber yang lain.

2. Di kelas yang hanya terdapat satu komputer, guru dapat melakukan kegiatan pembelajaran dengan mengadopsi game Jeopardy. Game ini merupakan permainan berbentuk kuis yang dimainkan bersamasama oleh guru dan seluruh siswa di kelas. Papan kuis Jeopardy untuk game di kelas cukup dibuat menggunakan Powerpoint. Aturan umum permainan dan langkah kegiatan dapat dikembangkan berdasarkan situasi yang akan dihadapi guru saat proses pembelajaran, khususnya saat pembelajaran remedial yang tidak memungkinkan pembentukan kelompok yang terdiri dari 4-5 orang. Sehingga guru harus memiliki keterampilan untuk memodifikasi aturan permainan dan langkah kegiatan tersebut.

3. Apabila peneliti lain ingin melakukan penelitian yang sejenis atau mengembangkan kedalam pembelajaran reguler, penelitian ini dapat dijadikan referensi dalam melakukan penelitian yang lebih komprehensif. Misalnya dengan mengembangkan pengukuran hasill belajar psikomotor atau afektif siswa, dapat pula dipraktekkan di kelas dengan tingkatan yang berbeda.

\section{DAFTAR PUSTAKA}

Abdurrahman, Mulyono. (2012). Anak Berkesulitan Belajar: Teori, Diagnosis, dan Remediasinya. Jakarta: Rineka Cipta.

Abdurrahman. (1993). Pengelolaan Pengajaran. Ujung Pandang: PT. Bintang Selatan.

Arifin, Zaenal. (2008). Metodologi Penelitian Pendidikan. Surabaya: Lentera Cendekia.

Arifin, Zaenal. (2009). Evaluasi Pembelajaran. Bandung: PT. Remaja Rosdakarya.

Arikunto, Suharsimi. (2010). Prosedur Penelitian. Jakarta: Rineka Ilmu.

Arikunto, Suharsimi. (2013). Dasar-Dasar Evaluasi Pendidikan. Jakarta: Bumi Aksara.

Arikunto, Suharsimi. (2013). Manajemen Pendidikan. Jakarta: Rineka Ilmu.

Bestiana, Y. (2014). Using Modified Game Jeopardy and Hop-Scotch To Improve English Vocabulary Mastery of Seventh Grades In SMP $N \quad 1$ Bondowoso. Vol, 2 No, 1. Surabaya 
Carwoto. (2012). "Pembelajaran di kelas dengan satu komputer permainan kuis turnamen Jeopardy". Dalam https://carwoto.wordpress.com. 2 Januari.

Casper, Virginia and Theilheimer, Rachel. (2010). Early Chidhood Education: Learning Together. Newyork: Mc Graw-Hill Campanies. Inc.

Creswell, John W. (2010). Research Design Pendekatan Kualitatif, Kuantitatif, dan Mixed. Yogyakarta: Pustaka Pelajar.

Darwansyah, dkk. (2009). Strategi Belajar Mengajar. Jakarta: Diadit Media.

Depdiknas. (2003). Undang-Undang tentang Sistem Pendidikan Nasional. Jakarta.

Depdiknas. (2008). Sistem Penilaian KTSP: Panduan Penyelenggaraan pembelajaran Remedial. Jakarta

Djamarah. (1994). Strategi Belajar Mengajar. Jakarta: Rineka Cipta

Dockett, Sue and Fleer, Marilyn. (2000). Play and Pedagogy in Early Childhood, Bending The Rules. Australia: Harcourt.

Elizabeth Wood \& Jane Attfield. (2005). Play, Learning and The Early Childhood Curriculum. London. Paul Chapman Publishing.

Farwaha Saroj S., Singh Baljit. and Dewan Rajni. (2013). "Effect of Remedial Programme on Development of Spelling Writing in English". International Educational E-Journal. Volume-II, Issue-IV, Oct-Nov-Dec 2013.

Gee, J. (2005). Good Video Games and Good Learning. Phi Kappa Phi Forum, 85 (2), 33-37. University of Wisconsin-Madison. Washington.

Hamalik, Oemar. (2003). Proses Belajar Mengajar. Jakarta: Bumi Aksara.

Hosnan, M. (2014). Pendekatan Saintifik dan Kontekstual dalam Pembelajaran abad 21: Kunci Sukses Implementasi Kurikulum 2013. Bogor: Ghalia Indonesia.

Jihad, A dan Haris, A. (2008). Evaluasi Pembelajaran. Jakarta: Multi Pressindo.

Kemdikbud. (2013). Panduan Teknis Pembelajaran Remedial dan Pengayaan Kurikulum 2013 Di Sekolah Dasar. Jakarta: Kemdikbud.
Kemdikbud. (2013). Peraturan Menteri Pendidikan dan Kebudayaan Nomor 66 Tahun 2013 Tentang Standar Penilaian. Jakarta: Kemdikbud.

Kustawan, Dedy. (2013). Analisis Hasil Belajar. Bandung: PT Luxima Metro Media.

Makmun, Abin Syamsudin. (2012). Psikologi Kependidikan Perangkat Sistem Pengajaran Modul. Bandung: PT. Remaja Rosda Karya.

Mills, Hanna and Mc Carroll, Elizabeth. (2012). "Emotion Regulation In Early Chidhood." Texas Child Care Quartely Vol. 36 No. 1. Sumber 2012 diunduh tanggal 28 November 2015.

Moeslichatoen. (2004). Metode Pengajaran di Taman Kanak-kanak. Jakarta: PT Rineka Cipta.

Mukhtar dan Rusmini. (2005). Pengajaran Remedial: Teori dan Pembelajarannya dalam Pembelajaran. Jakarta: PT Nimas Multima.

Nasution. (1982). Azas-azas Mengajar. Bandung: Jemmars.

Nasution. (2008). Metode Research (Penelitian Ilmiah). Jakarta: Bumi Aksara.

Riyanto, Yatim. (2007). Metodologi Penelitian Pendidikan Kualitatif dan Kuantitatif. Surabaya: Unesa University Press.

Rohwati, M. (2012). "Penggunaan Education Game untuk Meningkatkan Hasil Belajar IPA Biologi Konsep Klasifikasi Makhluk Hidup”. Jurnal Pendidikan IPA Indonesia (dipublikasikan). Universitas Negeri Semarang.

Sanjaya, Wina. (2006). Strategi Pembelajaran Berorientasi Standar Proses Pendidikan. Jakarta: Kencana Prenadamedia Group.

Sapriya. (2009). Pendidikan IPS, Konsep dan Pembelajaran. Bandung: Remaja Rosda Karya.

Sardiman. (2006). Interaksi dan Motivasi Belajar Mengajar. Jakarta: Rajawali Pers.

Sardiman. (2014). Interaksi dan Motivasi Belajar Mengajar. Jakarta: PT. Raja Grafindo Persada.

Sasmedi, D. (2012). Pemebalajaran Remedial. (Diakses di Copyright (C) LPMP Sulsel 2011 tanggal 25 November 2015

Scheel, E Robert dan Hall, Elizabeth. (1983). Development Psychology Today. American: Random House, Inc. 
Smaldino, Sharon E., Lowther Deborah L., \& Russel, James D. (2011). Instructional Technology \& Media for Learning. Inggris. Person Education, Inc.

Soekanto, Soerjono. (1990). Sosiologi Suatu Pengantar, Jakarta: Rajawali.

Somantri, Nu'man. (2001). Menggagas Pembaharuan Pendidikan IPS. Bandung: PPS-FPIPS UPI dan PT. Remadja Rosda Karya.

Sudjana, Nana. (2009). Penilaian Hasil Proses Belajar Mengajar. Bandung: PT. Remaja Rosda Karya.

Sugiyono. (2012). Metode Penelitian Kuantitatif, Kualitatif, dan $R \& D$. Bandung: Alfabeta.

Sujiono, Yuliani Nurani. (2013). Konsep Dasar Pendidikan Anak Usia Dini. Jakarta: Indeks.

Sumarsono, Sonny. (2004). Metode Riset Sumber Daya Manusia. Yogyakarta: Graha Ilmu.

Suprihatiningrum, J. (2013). Strategi Pembelajaran: Teori dan Aplikasi. Jogjakarta: Ar-Ruzz Media

Susanto, Ahmad. (2012). Teori Belajar dan Pembelajaran. Jakarta: Kencana Prenadamedia Group.

Susanto, Ahmad. (2014). Pengembangan Pembelajaran IPS di Sekolah Dasar. Jakarta: Prenadamedia Group.

Syah, Muhibbin. (2004). Psikologi Pendidikan. Bandung: Rajagrafindo Persada.

Tedjakusuma, Mayke Sugianto. (1994). Bermain, Mainan, dan Permainan. Jakarta: Depdikbud.

Usman, M.U. (2005). Menjadi Guru Profesional. Bandung: PT. Remaja Rosdakarya.

Wening. (2012). Bunda Sekolah Pertamaku. Solo: Tinta Medina. 